\title{
FLORISTIC INVENTORY OF THE PROPOSED SITE FOR TARSIER TOURISM CENTER IN VILLA AURORA, BILAR, BOHOL, PHILIPPINES
}

\section{TOMAS D. REYES JR.*, JERALYN B. ABADINGO, SHIELA G. TABUNO, EUNICE K.L. SERIÑO, JOECEL B. MABANAG, \& RIZALDY C. MERCADAL}

\author{
Bohol Island State University \\ CPG North Ave., 6300 Tagbilaran City, Bohol, Philippines \\ *Email: tomseyer@yahoo.com, tomseyer@gmail.com
}

\begin{abstract}
The study assessed the present vegetation composition of the Proposed Site for the Tarsier Tourism Center (PTTC) at Villa Aurora, Bilar, Bohol and performed a comparative analysis with the existing Tarsier Sanctuary (TS) at Canapnapan, Corella, Bohol. The basis for comparison was the computed importance values, species richness, species dominance, and percent distribution of plants according to self-defined DBH classes. Results showed that both sites had very high species richness and evenness values. Common overstorey and understorey plant species found in both areas were katagpo (Psychotria sp.), sagimsim (Syzygium brevistylum [C. B. Rob]Merr.) and bagauak (Clerodendrum minahassae Teijsm. \& Binn.). Apart from sagimsim (Syzygium brevistylum [C.B.Rob.] Merr.), selaginella (Selaginella cuppresina Lin.), and lunas (Lunasia amara Blanco) were also common in the ground vegetation of both areas. Percent distribution of trees according to self-defined DBH classes revealed that PTTC had $87.55 \%$ of the total recorded plants with DBH measurements of $\leq 10 \mathrm{~cm}$. Our data was found lower by almost $10 \%$ from TS. Considerable percentages of trees were also shared in other DBH classes for PTTC. DBH class range of 10-20 cm had 6.88\%, while $5.58 \%$ was computed for DBH class of $>20 \mathrm{~cm}$. Percent distribution of trees on these DBH ranges (especially on DBH class $>20 \mathrm{~cm}$ ) indicated the presence of medium and large trees. The largest DBH measured in the PTTC was $70 \mathrm{~cm}$ while in TS was only $22 \mathrm{~cm}$. The proposed 10-ha site in Villa Aurora, Bilar, is suited to be utilized as Tarsier Tourism Center. In case the proposed project is to be pursued, enclosure similar to what has been constructed in Canapnapan, Corella, Bohol, Philippines should also be established to prevent stray animals from predating the captive tarsiers.
\end{abstract}

Keywords: floristic inventory, Philippine tarsier, Bohol, primate conservation, tourism.

\section{INTISARI}

Penelitian ini ditujukan untuk melakukan penilaian komposisi vegetasi dari Usulan Lokasi Pusat Wisata Tarsius (ULPWT) di Villa Aurora, Bilar, Bohol dan melakukan analisis perbandingan antara Tarsier Sanctuary (TS) yang ada di Canapnapan, Corella, Bohol. Dasar perbandingan yang digunakan yaitu dengan menghitung nilai penting, kekayaan spesies, dominansi spesies, dan prosentase distribusi dari tumbuhan berdasarkan kelas diameter yang telah ditentukan. Hasil penelitian menunjukkan bahwa kedua tempat memiliki kekayaan spesies dan nilai evenness/kemerataan yang sangat tinggi. Spesies tumbuhan yang umum ditemukan di overstorey dan understorey di kedua area adalah katagpo (Psychotria sp.), sagimsim (Syzygium brevistylum [C. B. Rob]Merr.), dan bagauak (Clerodendrum minahassae Teijsm. \& Binn.). Selain itu, sagimsim (Syzygium brevistylum [C.B.Rob.] Merr.), selaginella (Selaginella cuppresina Lin.), dan lunas (Lunasia amara Blanco) juga umum ditemukan di lantai hutan di kedua tempat. Prosentase distribusi dari tumbuhan berdasarkan kelas diameter yang telah ditentukan menunjukkan bahwa ULPWT memiliki 87.55\% dari keseluruhan tumbuhan yang tercatat dengan ukuran diameter $\leq 10 \mathrm{~cm}$. Data kami menunjukkan bahwa nilai tersebut lebih rendah 10\% dari TS. Sebagian persentase dari pohon juga dimiliki di ULPWT pada kelas 
diameter lainnya. Kelas diameter 10-20 cm memiliki 6,88\%, sementara 5,58\% terhitung untuk kelas diameter $>20 \mathrm{~cm}$. Prosentase distribusi dari pohon pada kisaran ini (khususnya pada diameter $>20 \mathrm{~cm}$ ) menunjukkan adanya kehadiran pohon berukuran medium dan besar. Diameter terbesar yang terukur di ULPWT adalah 70 cm sementara di TS hanya sebesar $22 \mathrm{~cm}$. Lokasi seluas 10 ha di Villa Aurora, Bilar, sesuai untuk digunakan sebagai Pusat Wisata Tarsius. Apabila akan didirikan, maka kandang yang dibangun diharapkan mirip dengan yang telah dibangun di Canapnapan, Corella, Bohol, Pilipina, agar mencegah pemangsaan oleh satwa yang lepas.

Kata kunci: inventarisasi floristic, Philippine tarsier, Bohol, konservasi primata, wisata.

\section{INTRODUCTION}

The Philippine tarsier or Tarsius syrichta (Linne) has attracted a lot of attention of scientists and collectors because of its interesting physical features and habits. It is often fancied as a crossbreed of a bat and a rat. A specific trait of the elongated tarsal region derived the name of "tarsier" (Embury, 1994). Its size is no bigger than two fists held together. The Philippine tarsier, with three subspecies: syrichta, fraterculus, and carbonarius, is one of the smallest among the different known species (Hill, 1955). This trait and its rarity status would be the reason this creature is on the CITES endangered list. The status was "lower risk conservation dependent" based on the IUCN 2004, and then became "data deficient" in 2006, and now under the "near-threatened" category since 2008 (Shekelle and Arboleda, 2008).

The Philippine tarsier habitats are primarily located in the secondary lowland rainforest of earlyto mid-succession stage (Neri-Arboleda et al., 2002; Reyes, 2006). In Bohol, it occurs in hilly areas with patches of second-growth forest (PAWB-DENR, 1992; Lagapa, 1993; Villamor, 1995; Reyes, 2006), bushes, bamboos, palms, and some grasses (Karnain, et al., 1997; Reyes, 2006). The short trees, as well as bamboos, are good for the arboreal adaptation by the tarsiers. The dense nature of the undergrowth supports a wide variety of insects and small vertebrates which are vital to the survival of tarsiers. The close distance between small diameter trees, on the other hand, appears to be a necessary condition which favors the locomotive behavior of tarsiers. These conditions, thus enabling them to have a firm grasp of the small trunks and branches making this type forest a favorable place to live (Villamor, 1995; Karnain, et al., 1997). Abandoned clearings with signs of new growth of medium-high plants in lands of both low and medium elevations were also used by tarsier (Hoogstraal, 1947). These types of clearing were believed to be the tarsier's feeding sites (Rabor, 1977; Villamor, 1995) until disproved by Neri-Arbodela et al. (2002).

Habitat characterization of the Philippine tarsier has been conducted in Bohol by several local researchers and research institutions (Madulid [undated]; PAWB, 1992; Lagapa, 1993; Villamor, 1995; Neri-Arboleda et al., 2002; Reyes, 2000\&2006; and ERDS, 2009). Among those researchers, Neri-Arboleda et al. (2002) and Reyes (2006) provided detailed discussions on several habitat classifications. Reyes (2006), in particular, described 11 variants of the tarsier's roosting territories based on species composition and thicket structure. He also correlated the presence of tarsiers and its scent-markings on the abundance of small diameter plants in his study sites. The establishment of Tarsier Tourism Area in Villa Aurora, Bilar has 
been proposed. To assess the suitability of the proposed site, we compared vegetation composition of the proposed tarsier tourism site (PTTC) at Villa Aurora, Bilar, Bohol, Philippines and the existing tarsier sanctuary at Canapnapan, Corella, Bohol, Philippines (TS). The findings of the study of Reyes (2006), on this aspect, were used as the basis for evaluating the suitability of proposed Tarsier Tourism Area in Villa Aurora, Bilar, apart from the usual species richness and dominance assessment.

\section{MATERIALS AND METHODS}

The Proposed Tarsier Tourism Center (PTTC) is planned at Barangay Villa Aurora in the municipality of Bilar the Philippines. The total area of the proposed tourism site is 10.194 ha (CENRO-Tagbilaran, 2013). It is located along the stretch of the prominent winding road of Barangay Villa Aurora, a kilometer away from the "famous Bilar-Loboc Man-made Mahogany Plantation. The area will serve as an extension of the 6-haTarsier Tourism Area established at Upper Bonbon, Loboc, Bohol, the Philippines. Also, for a comparison, the Tarsier Sanctuary and Conservation Site (TS) is situated at Barangay Canapnapan in the municipality of Corella, Bohol, the Philippines. This 134-ha conservation site is managed by the Philippine Tarsier Foundation Incorporated (PTFI) and is open to the public, since the 1990 s, for recreation and research.

Quadrat sampling was used in the collection of data. Twenty quadrats (=plots) were established preferentially within the 10-ha PTTC in Villa Aurora, Bilar. The $10 \times 10 \mathrm{~m}$ plots were laid selectively on thickets of small diameter trees and shrubs which could be identified as potential roosting sites of the Philippine tarsier. All plants with a diameter at breast height $(\mathrm{DBH})$ of $\geq 1 \mathrm{~cm}$ were recorded. Small nested subplot with a dimension of 1 $\mathrm{x} 1 \mathrm{~m}$ was also established in the middle of each plot to facilitate the identification of the ground vegetation. For comparative analysis, ten plots and subplots were also established at TS in Canapnapan, Corella. The first five plots and subplots were laid in the PTFI tarsier enclosure where visitors are allowed to enter and see the captive tarsiers, and the remaining plots and subplots were laid outside the enclosure, about $30 \mathrm{~m}$ away from the PTFI building.

Analysis of data was mainly concentrated on the determination of species abundance parameters such as density, frequency, and dominance values of each plant species. These parameters were used in the calculation of importance value (IV) of all encountered plants in the overstorey, understorey, and ground vegetation. The IV is a measure of species abundance in an area. It is the summation of the relative values of density (number of species per unit area), frequency (number of occurrences of species relative to the number of plots established) and dominance (basal area of species relative to the total computed basal areas).

For the purpose of comparison of the two sites, species richness, and dominance indices like diversity (Shannon-Wiener diversity index), evenness (Evenness index), and dominance (Simpson's index) were computed based on the importance value. The Shannon-Weiner diversity index assumes that individuals are randomly sampled from an indefinitely large population and also assumes that all species are represented in the sample. Evenness index, on the other hand, is the ratio of observed diversity to maximum diversity, while Simpson's index is the probability of any two individuals drawn at random from an infinitely large community belonging to same species. 
The density of plants, in percent (\%), on each pre-defined diameter class was also calculated to evaluate the suitability of the proposed site for tarsier conservation as the project proponents (wildlife permits from Loboc) claimed its very purpose. The comparison was based on the work of Reyes (2006) who tested the relationship of DBH to the number of tarsiers seen in the wild. DBH classes used in this study were: $\leq 10 \mathrm{~cm} ; 10-20 \mathrm{~cm}$; and $>20 \mathrm{~cm}$. The calculation of formulas was adopted from Gruezo (1997), Fernando et al. (1998), Reyes (2000 \& 2006), and ERDS (2009).

\section{RESULTS AND DISCUSSION}

\section{Overstorey and Understorey Plants}

A total of 112 species of overstorey and understorey plants were identified in the PTTC at Villa Aurora, Bilar. These belonged to 82 genera under 44 families (Figure 1).The recorded plant species and genera in PTTC were roughly twice those in TS. Tables 1 and 2 show the summary lists of common overstorey and understorey plants in both areas. From the list in Table 1, the first three most common species were katagpo (Psychotria $s p$.), bayukbok (Elaeocarpus macranthus Merr.) and langin (Micromelum caudatum Merr.) based on the computed IV of 28.96, 10.94, and 10.62. The three most common species in Table 2, on the other hand, were alabihig (Arthrophyllum diversifolium Blume), tagoanguak (Croton leiophyllus Muell.-Arg.), and katagpo (Psychotria sp.) with IVs of 29.70, 19.91, and 19.77, respectively. As shown in Tables 1 and 2, the species of plants which were found in both areas, apart from katagpo, were sagimsim (Syzygium brevistylum (C.B. Rob.) Merr.) and bagauak (Clerodendrum minahassae Teijsm. \&Binn.).

There were also 52 species, 43 genera, and 35 families of ground vegetation in the PTTC. Same with the overstorey and understorey vegetation, its ground cover was more than twice species-rich that the recorded ground vegetation in TS. Table 3 presents the summary list of common plants species identified on the ground based on the number of individuals. The most common species recorded with more than 30 individuals each, in reverse order, were sagimsim (Syzygium brevistylum [C. B. Rob.] Merr.),

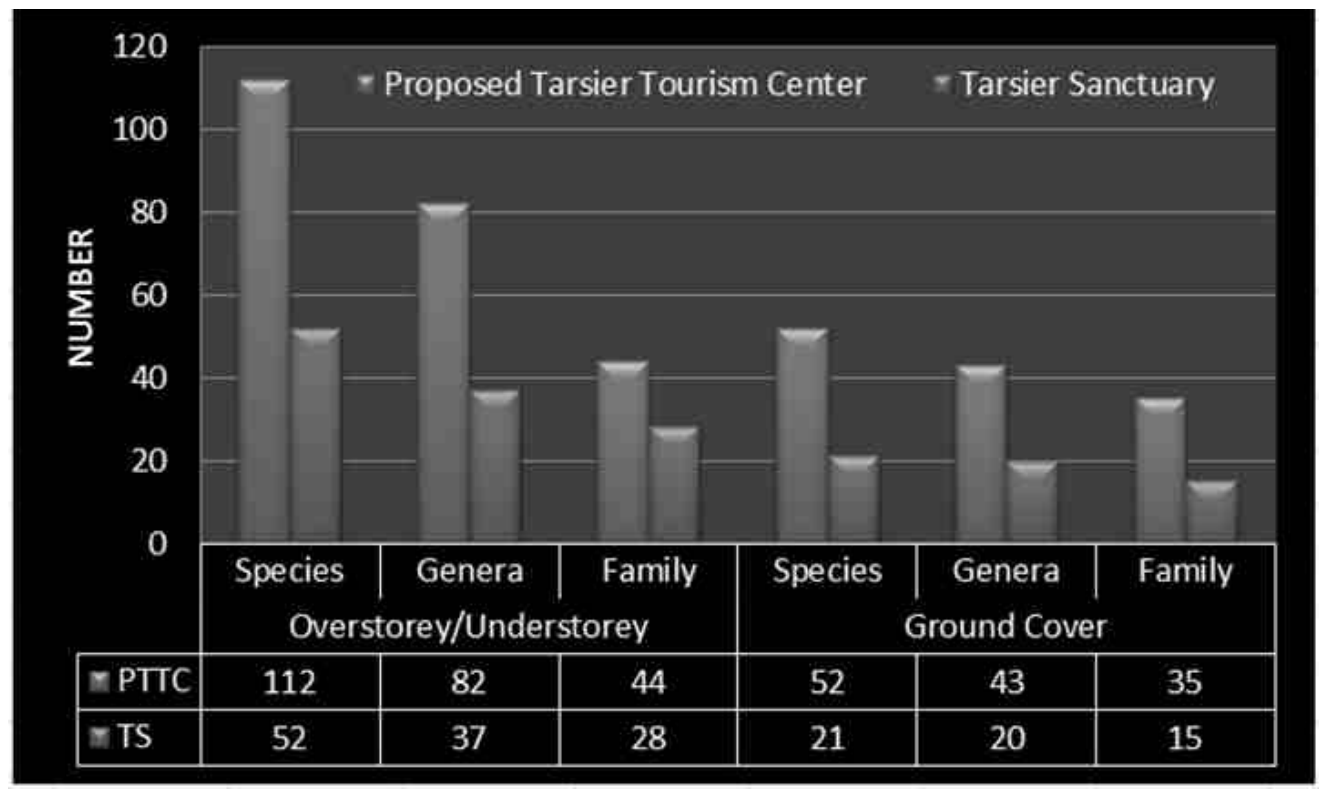

Figure 1. Taxonomic information of the Proposed Tarsier Tourism Center, Villa Aurora, Bilar and Tarsier Sanctuary, Canapnapan, Corella, Bohol, Philippines. 
Table 1. List of common overstorey and understorey plants arranged based on importance values in PTTC, Villa Aurora, Bilar, Bohol, Philippines

\begin{tabular}{lllc}
\hline \multicolumn{1}{c}{ Common Name } & \multicolumn{1}{c}{ Scientific Name } & \multicolumn{1}{c}{ Family Name } & $\begin{array}{c}\text { Important } \\
\text { Value }\end{array}$ \\
\hline Katagpo & Psychotria sp. & Rubiaceae & 28.96 \\
Bayukbok & Elaeocarpus macranthus Merr. & Elaeocarpaceae & 10.94 \\
Langin & Micromelum caudatum Merr. & Rutaceae & 10.62 \\
Sagimsim & Syzygium brevistylum (C.B. Rob.) Merr. & Myrtaceae & 9.89 \\
Paginga & Discocalyx cybianthoides (A.DC.) Mez. & Myrsinaceae & 7.80 \\
Katongmatsin & Chisocheton pentandrus (Blanco) Merr. & Meliaceae & 7.18 \\
Bagauak & Clerodendrum minahassaeTeijsm. \&Binn. & Lamiaceae & 6.98 \\
Batino & Alstonia macrophylla Wall. ex DC. & Apocynaceae & 6.72 \\
Malak-malak & Palaquium philippense (Perr.) C.B. Rob. & Sapotaceae & 6.52 \\
Big-leaf mahogany & Swietenia macrophylla King. & Meliaceae & 6.44 \\
Aniam-gubat & Antidesma subolivaceum Elm. & Euphorbiaceae & 6.35 \\
Malaikmo & Celtis philippensis Blanco & Ulmaceae & 6.05 \\
Talanggubat & Diospyros copelandii Merr. & Ebenaceae & 5.79 \\
Alahan & Guioa koelreuteria (Blanco) Merr. & Sapindaceae & 5.74 \\
Lunas & Lunasia amara Blanco & Rutaceae & 5.62 \\
Duguan & Myristica philippensis Lam. & Myristicaceae & 5.51 \\
Palosapis & Anisoptera thurifera (Blanco) Blume & Dipterocarpaceae & 5.23 \\
\hline
\end{tabular}

Table 2. List of common overstorey and understorey plants arranged based on importance values inTS, anapnapan, Corella, Bohol, Philippines

\begin{tabular}{lllc}
\hline \multicolumn{1}{c}{ Common Name } & \multicolumn{1}{c}{ Scientific Name } & Family Name & $\begin{array}{c}\text { Important } \\
\text { Value }\end{array}$ \\
\hline Alabihig & Arthrophyllum diversifolium Blume & Araliaceae & 29.70 \\
Tagoanguak & Croton leiophyllus Muell.-Arg. & Euphorbiaceae & 19.91 \\
Katagpo & Psychotria sp & Rubiaceae & 19.77 \\
Sagimsim & Syzygium brevistylum (C.B. Rob) Merr. & Myrtaceae & 19.50 \\
Balinghasai & Buchanania arborescens Blume & Anacardiaceae & 18.30 \\
Bagauak & Clerodendrum minahassaeTeijsm. \&Binn. & Lamiaceae & 14.04 \\
\hline Matangarau & Melico petriphylla (Lam.) Merr & Rutaceae & 13.74 \\
Takipasin & Macaranga grandifolia (Blanco) Merr. & Euphorbiaceae & 10.08 \\
Sudiang & Ctenolophon philippinense Hallier F. & Linaceae & 8.19 \\
& Mussaenda sp & Rubiaceae & 8.01 \\
Niog-niogan & Ficus pseudopalma Blanco & Moraceae & 7.93 \\
Pandangubat & Freycinetia sp & Pandanaceae & 7.83 \\
Kubi & Artocarpus nitida Trec. sub sp. nitida & Moraceae & 6.77 \\
Molave & Vitex parviflora Juss. & Lamiaceae & 5.66 \\
Tambo & Thysonolaena latifolia (Roxb. ex Hornem.) & Poaceae & 5.23 \\
& Honda & & \\
Ficus & Ficus sp & Moraceae & 5.14 \\
\hline
\end{tabular}


selaginella (Selaginella cuppresina), and lunas (Lunasia amara Blanco). These species were also listed common in TS, as shown in Table 4.

\section{Species Richness and Dominance}

The results of species richness and dominance computations (Figure 2) revealed that both sites were species-rich given by Shannon-Weiner diversity index values of 4.26 for PTTC and 3.56 for TS. According to Fernando et al. (1998), diversity index values above 3.5 are considered very high. Values of the dominance indices such as evenness and Simpson's dominance index also supported this finding. Evenness values of almost 1.0 (0.9031 for PTTC and 0.9012 for TS) mean that the observed (or computed) diversity value is almost equal to the expected maximum diversity value (Gruezo, 1997; Fernando et al., 1998; Reyes, 2000). A very high evenness index was accompanied by a very low dominance index. For both sites, Simpson's dominance index values were computed less than 0.04 . This value means that there is only less than $4 \%$ chance that two individual plants selected in both sites would belong to the same species. Reyes (2000) reported that the species diversity in the identified six roosting territories of the Philippine tarsier in Barangay Cabacnitan, Bilar ranged from 2.01 (low) to 3.125 (high).

\section{Self-defined DBH Classes}

The computation of percent distribution of plants in three different self-defined DBH classes (Table 5) showed that PTTC had $87.55 \%$ of the total recorded plants with DBH measurements of $\leq 10 \mathrm{~cm}$. The value was found lower by almost $10 \%$ from TS. Considerable percentages of trees were also shared in other DBH classes for PTTC. DBH class range of $10-20 \mathrm{~cm}$ had $6.88 \%$ while $5.58 \%$ was computed for

Table 3. List of common plants species comprising the ground vegetation arranged based on the number of individuals in PTTC, Villa Aurora, Bilar, Bohol, Philippines.

\begin{tabular}{lllc}
\hline \multicolumn{1}{c}{ Common Name } & \multicolumn{1}{c}{ Scientific Name } & Family Name & Individuals \\
\hline Sagimsim & Syzygium brevistylum (C.B. Rob.) Merr. & Myrtaceae & 53 \\
Selaginella & Selaginella cuppresina & Selaginellaceae & 40 \\
Lunas & Lunasia amara Blanco & Rutaceae & 38 \\
& Flacourtia sp. & Flacourtiaceae & 27 \\
Langin & Micromelum caudatum Merr. & Rutaceae & 22 \\
Tubli & Derris sp & Fabaceae & 20 \\
Paginga & Discocalyx cybianthoides (A. DC.) Mez. & Myrsinaceae & 17 \\
Takipan & Caryota rumphiana Mart. var. philippinensis & Arecaceae & 11 \\
& Becc. & & \\
White nato & Pouteri amacrantha (Merr.) Baehni & Sapotaceae & 11 \\
\hline
\end{tabular}

Table 4. List of common plants species composing the ground vegetation arranged based on the number of individuals in TS, Canapnapan, Corella, Bohol, Philippines.

\begin{tabular}{lllc}
\hline Common Name & \multicolumn{1}{c}{ Scientific Name } & Family Name & Individuals \\
\hline Sagimsim & Syzygium brevistylum (C.B. Rob) Merr. & Myrtaceae & 49 \\
Selaginella & Selaginella cuppresina & Selaginellaceae & 40 \\
Langin & Micromelum caudatum Merr. & Rutaceae & 27 \\
Tagpo & Ardisia squamulosa Presl. & Myrsinaceae & 15 \\
Nino & Morinda bracteata Roxb. & Rubiaceae & 10 \\
\hline
\end{tabular}




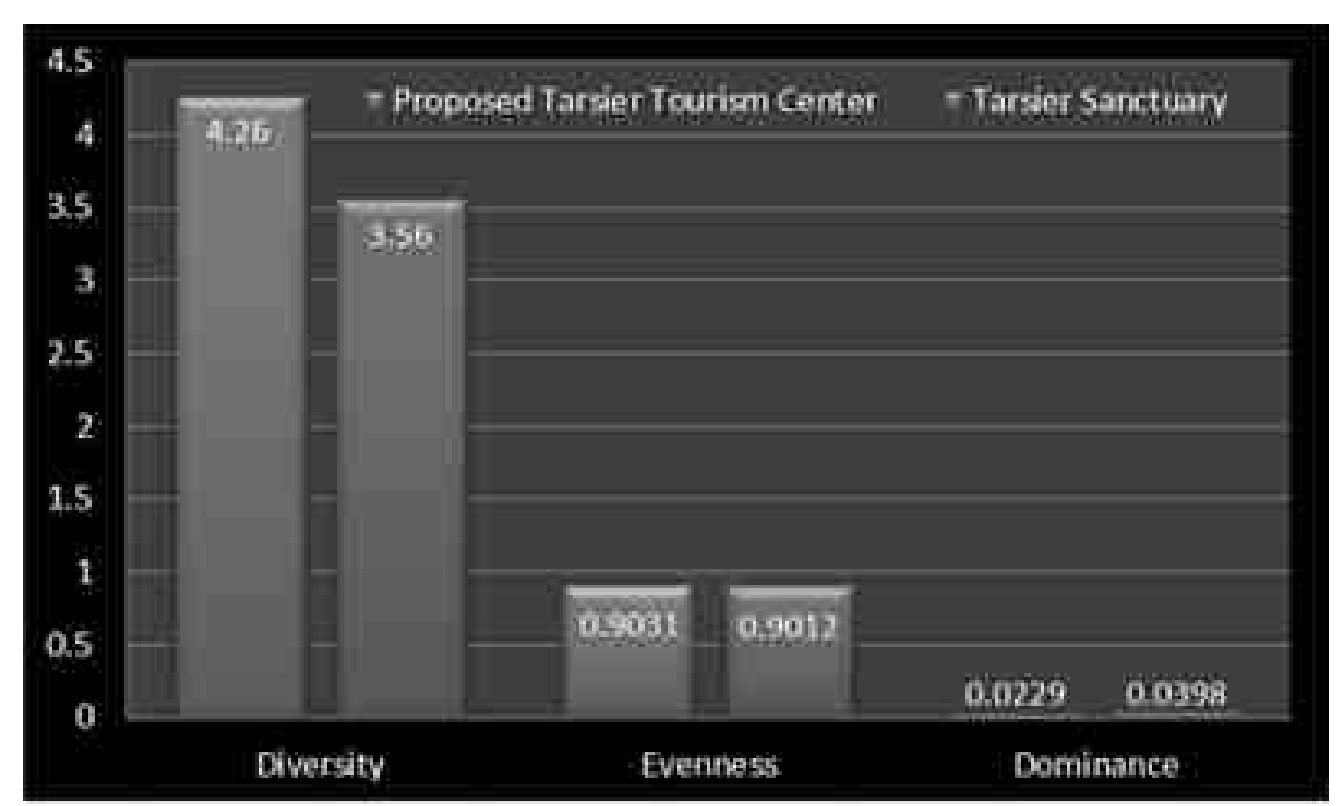

Figure 2. Species richness and dominance index values for the Proposed Tarsier Tourism Center, Villa Aurora, Bilar and Tarsier Sanctuary, Canapnapan, Corella, Bohol, Philippines

DBH class of $>20 \mathrm{~cm}$. Percent distribution of trees on these DBH ranges (especially on DBH class $>20 \mathrm{~cm}$ ) indicated the presence of medium and large trees. The largest DBH measured in PTTC was $70 \mathrm{~cm}$. For TS, only less than $3 \%$, combined, was computed for DBH classes of $>10 \mathrm{~cm}$. The largest DBH measured was $22 \mathrm{~cm}$.

Table 5. Percent distribution of plants in self-defined DBH classes

\begin{tabular}{lccc}
\hline \multirow{1}{*}{ Study Site } & \multicolumn{3}{c}{ DBH Class (cm) } \\
& $\leq 10$ & $10-20$ & $>20$ \\
\hline $\begin{array}{l}\text { Proposed Tarsier Tourism } \\
\text { Center }\end{array}$ & 87.55 & 6.88 & 5.58 \\
$\begin{array}{l}\text { Tarsier Sanctuary and } \\
\text { Conservation Site }\end{array}$ & 97.13 & 2.01 & 0.86 \\
\hline
\end{tabular}

\section{CONCLUSION}

The proposed 10-ha site in Villa Aurora, Bilar, is suited to be utilized as Tarsier Tourism Center. Apart from the site's inherent diversity in plant species, the current vegetation composition and the presence of medium and large size trees in PTTC suggests its similarity to one of the variants described by Reyes
(2006) as advance thickets of many small diameter trees, few medium- and large-sized trees and dense undergrowth. However, in case the proposed project will be pursued, enclosure similar to what has been constructed in Canapnapan, Corella should also be established to prevent stray cats and other animals from predating the captive tarsiers.

\section{REFERENCES}

CENRO-Tagbilaran. 2013. Map of the Proposed Tarsier Tourism Site at Villa Aurora, Bilar. CENRO Tagbilaran, DENR.

ERDS. 2009. Floral and Faunal Assessment of the Proposed Tarsier Sanctuary in Corella, Bohol. Unpublished Technical Report. Ecosystems Research and Development Services (ERDS) Region 7, DENR.

Fernando E, Jumawid RJ, \& Peras J. 1998. Resource Inventory and Assessment of Biodiversity in the Subic Bay Metropolitan Authority Area. Unpublished Terminal Report. UPLB-SBMA-PCARRD-DOST.

Gruezo WSM. 1997. Floral diversity profile of Mount Makiling Forest Reserve, Luzon, Philippines, In : The Conditions of Biodiversity Maintenance in Asia. Dore MR \& Sajise PE. (Eds.). East-West Center, Honolulu, Hawaii. 
Hill WCO. 1955. Primates: Comparative Anatomy and Taxonomy. II. Haplorhini: Tarsioidea. Edinburgh University Press, Edinburgh, Scotland.

Hoogstraal H. 1947. The inside story of the tarsier. Chicago Natural History Museum Bulletin 18, 7-8 (Nov.); 4-5 (Dec.).

Lagapa EPG. 1993. Population Estimates and Habitat Analysis of the Philippine Tarsier (Tarsius syrichta L.) in Bohol. Bachelor's Thesis. University of the Philippines, Los Baños.

Madulid DA. (undated).Vegetation Analysis of the Forest in Corella, Bohol. Unpublished Report. National Museum, Manila.

Neri-Arboleda I, Scott P, \& Arboleda NP. 2002. Home ranges, spatial movements, and habitat associations of the Philippine tarsier (Tarsius syrichta L.) in Corella, Bohol. Journal of Zoology 257, 387-402.

PAWB-DENR, 1992.The Philippine Tarsier. Philippine Wildlife Series No. 2.PAWB-DENR.

Rabor D. 1977. Philippine Birds and Mammals. University of the Philippines Press, Baltimore.

Reyes TD JR. 2000. Population estimation, habitat characterization, and mapping of identified Philippine Tarsier (Tarsius syrichta Linne.) territories in Cabacnitan, Bilar, Bohol. Tropical Technology Journal 3(4). October-December 2000. ISSN 1656-0264.

Reyes TD JR. 2006. Plant-Environment Relations in the Philippine Tarsier (Tarsius syrichta Linne.) Habitats. Unpublished Master Thesis. Wageningen University and Research Centre. The Netherlands.

Shekelle M \& Arboleda I. 2008. Tarsius syrichta. The IUCN Red List of Threatened Species. Version 2015.2. <www.iucnredlist.org>. Downloaded on 29 August 2014.

Villamor CI. 1995. Captive Breeding of Philippine Tarsier (Tarsius syrichta L.). Terminal Report. ERDB-DENR and PCARRD-DOST Project. 